Deutsche Botschaften

jovis research 2 
Gedruckt mit freundlicher Unterstützung des Förderungsfonds Wissenschaft der VG Wort und der Geschwister Boehringer Ingelheim Stiftung für Geisteswissenschaften in Ingelheim am Rhein. 


\section{Christiane Fülscher}

\section{Deutsche Botschaften}

\section{Zwischen Anpassung und Abgrenzung}

